\section{URGENSI OBITER DICTA DALAM PUTUSAN HAKIM PERKARA PERDATA ${ }^{1}$ Oleh: Masni Larenggam ${ }^{2}$}

\begin{abstract}
ABSTRAK
Tujuan dilakukannya penelitian ini adalah untuk mengetahui bagaimana keadilan dan kepastian hukum dalam putusan Hakim bisa terwujud bagi para pencari keadilandan bagaimana penerapan obiter dicta putusan hakim dalam perkara perdat. Dengan menggunakan merode penelitian hukum normatif disimpulkan bahwa: 1. Keadilan dan kepastian hukum merupakan dua entitas yang tidak dapat dipisahkan yaitu: a. Keadilan adalah sebagai tujuan tertinggi hukum (The Ultimate Goal) yang ingin dicapai dalam suatu penegakkan hukum, keadilan adalah cita-cita luhur yang lahir dan senantiasa tumbuh bersama masyarakat; b. Kepastian hukum sebenarnya dapat dipahami sebagai buah proses atau dinamika hukum yang selama ini hidup dan berkembang dan dijalani oleh masyarakat yang dimaksud adalah yang memenuhi tiga kriteria umum yaitu: Ius constitutum; lus constituendum; lus operatum.

2. Obiter Dicta merupakan pernyataan dan proposisi hakim dalam mempertimbangkan suatu kasus atau perkara yang sedang ditanganinya tentang tidak secara langsung bersentuhan atau berkaitan dengan pokok perkara (not directly relevant to the case). Obiter dicta secara implisit terdapat dalam Pasal 170 HIR dan Pasal 1906 KUHPerdata.

Kata kunci: perkara perdata, obiter dicta
\end{abstract}

\section{PENDAHULUAN}

\section{A. Latar Belakang Masalah}

HIR/R.Bg telah memberikan pedoman kepada para hakim bagaimana prosedur yang tepat dalam mengadili dan memutus suatu perkara. Sebelum menentukan konklusi (judgment) terhadap setiap bagian gugatan Penggugat, hakim wajib untuk mencukupkan alasan-alasan atau pertimbangan hukumnya (ratio decidendi; reasons of the judgment), baik dari pemahaman secara utuh terhadap fakta-

\footnotetext{
1 Artikel sskripsi. Pembimbing skripsi: Gress Thelma Mozes, $\mathrm{SH}, \mathrm{MH}$; Constance Kalangi, $\mathrm{SH}, \mathrm{MH}$; dan Drs. Frans Kalesaran, SH, M.Si, MH

2 Mahasiswa Fakultas Hukum Universitas Sam Ratulangi, Manado; NIM: 110711551.
}

fakta di persidangan maupun terhadap segenap peraturan perundang-undangan yang berlaku maupun hukum tidak tertulis yang melingkupi kasus atau perkara yang sedang ditangani (consider all of the circumstances of the case). Dengan implementasi hal tersebut, maka putusan hakim tidak akan dikualifikasi sebagai onvoldoende gemotiveerd.

Kualitas suatu putusan hakim serta tingkat kecerdasan dan intelektualitas yang dimilikinya akan direfleksikan sekaligus dipertaruhkan pada bagaimana hakim merumuskan ratio decidendi dalam putusannya. Penalaran hukum (legal reasoning) serta rumusan argumentasi hukum (legal argumentation) akan menggambarkan kecermatan dan tingkat intelektualitas hakimnya. Hakim dalam merumuskan putusannya tidak hanya berkutat pada silogisme formal belaka, bukan juga sekadar menafsir secara mekanis, melainkan sebagai pekerjaan intelektual yang membutuhkan analisis dan penafsiran secara komprehensif. ${ }^{3}$

Begitu pentingnya arti dan kedudukan putusan yang kemudian melambangkan mahkota hakim, hakim pada akhirnya dituntut untuk senantiasa mengerahkan daya cipta, rasa, dan karsa yang dimilikinya untuk memutus dengan seadil-adilnya. Dalam konteks demikian, hakim harus memperhatikan sekalian instrumen hukum yang melingkupi suatu perkara (perundang-undangan, konteks kasus atau perkara) serta hal-hal lain di luar hukum itu sendiri (aspek filosofi, sosiologi, antropologi, dan psikologi).

\section{B. Rumusan Masalah}

1. Bagaimana keadilan dan kepastian hukum dalam putusan Hakim bisa terwujud bagi para pencari keadilan?

2. Bagaimana penerapan obiter dicta putusan hakim dalam perkara perdata?

\section{Metode Penelitian}

Penulis dalam menyusun skripsi ini menggunakan metode penelitian kepustakaan yang bersifat yuridis normatif. Sebagai ilmu normatif (ilmu hukum perdata), membantu memecahkan persoalan-persoalan hukum yang

\footnotetext{
3 Basuki Rekso Wibowo, Pembaruan Hukum yang Berwajah Keadilan, artikel, Majalah Hukum Varia Peradilan Tahun XXXVII No. 313 Desember 2011, hal. 19
} 
dihadapi oleh masyarakat. ${ }^{4}$ Dengan tujuan agar dapat menemukan fakta-fakta (fact finding) sebagaimana yang diungkapkan oleh Soerjono Soekanto, ${ }^{5}$ agar bisa terwujud fakta di lapangan terhadap aplikasi ketentuan hukum yang ada dan hidup dalam masyarakat.

\section{PEMBAHASAN}

\section{A. Keadilan dan Kepastian Hukum Dalam Putusan Hakim}

Dialektika antara hukum dan masyarakat terjadi dalam kerangka dialektika transformatif. Artinya, bahwa dialektika antara hukum dan masyarakat senantiasa berlangsung secara dinamis mengikuti perkembangan dan kebutuhan zaman. Sebagai contoh, pada masa lalu, hukum hanya dipandang mengatur tentang perikatan yang menghadirkan pihakpihak dalam satu tempat dan saling berhadaphadapan untuk mengutarakan maksudnya secara verbal. Seiring dengan perkembangan zaman dan teknologi yang kian canggih menerobos batas ruang dan waktu, perikatan tidak lagi hanya dilakukan secara konvensional, melainkan dapat dilakukan antar daerah, bahkan antar negara tanpa harus mempertemukan secara fisik pihak-pihak yang melakukan perikatan.

Situasi tersebut menuntut adanya transformasi (perubahan), baik dalam sistem maupun dalam operasionalisasi hukum. Hukum tidak lagi hanya boleh mengatur tentang perikatan yang dilakukan secara konvensional, melainkan juga harus mengatur hal-hal lain yang menerobos tradisi konvensional tersebut (beyond traditional ways). ${ }^{6}$

Inilah sesungguhnya makna kepastian hukum, yaitu suatu keadaan dalam hukum itu sendiri yang menyesuaikan dengan keadaan dan kebutuhan masyarakat. Hukum, merupakan sistem yang autopoetic, yaitu sistem yang di dalamnya berjalan suatu mekanisme untuk mengadaptasi diri dengan perubahan pada lingkungan eksternalnya yang dapat mewujud pada produksi sub sistem-sub sistem baru. Seperti pada contoh yang

\footnotetext{
4 Johny Ibrahim, Teori dan Metodologi Penelitian Hukum Normatif, Bahu Media, Surabaya, 2007, hal. 52

5 Soerjono Soekanto, Pengantar Penelitian Hukum, Jakarta, UI Press, 1986, hal. 50-51

${ }^{6}$ Ibid, hal. 116
}

disebutkan sebelumnya, hukum akan menyesuaikan dirinya dengan kebutuhan akan perikatan yang menembus batas ruang dan waktu, antara lain dengan memproduksi sub sistem baru, yaitu peraturan-peraturan baru yang mengakomodir hal dimaksud.

Dengan demikian, pemaknaan kepastian hukum perlu direkonstruksi ulang, karena selama ini, hemat penulis, kepastian hukum cenderung dimaknai sebagai status quo, suatu keadaan yang sudah menetap dan cenderung dipertahankan untuk menjaga kestabilan suatu aturan. Meskipun pada kenyataannya, mempertahankan hal tersebut pada hakikatnya mempertahankan sesuatu yang sudah usang (out to date), tidak logis (unlogic), dan tidak aplikatif (not aplicable). ${ }^{7}$

Pula dengan keadilan, yang selama ini dipersepsikan sebagai sesuatu yang berada jauh di atas hukum, melampaui batas-batas normatif hukum itu sendiri. Dalam sebuah pengertian sederhana, keadilan digambarkan sebagai sebuah eksistensi transenden, sehingga mewujudkannya dipandang akan menerobos aturan-aturan normatif yang bersifat pasti (certainty), terbatas (limited), dan kaku (rigid). ${ }^{8}$ Seringkali dijumpai asumsi-asumsi yang sentimentil tentang penegakan keadilan yang bertentangan dcngan aturan hukum yang ada. Contra legem yang dilakukan oleh hakim dalam putusannya adalah contoh sederhana untuk menggambarkan kesalahan persepsi tentang apa dan bagaimana keadilan itu.

Contra legem pada asasnya dilakukan oleh hakim ketika suatu aturan hukum yang diterima dan berlaku tidak merepresentasikan cita dan aspirasi keadilan serta nilai-nilai luhur yang tumbuh dan berkembang di masyarakat. Hakim dalam mengadili suatu perkara, terlebih yang menganut pandangan progresifitas dan responsifitas hukum, akan berani membuat semacam antitesa terhadap bunyi dan keberlakuan aturan dalam undang-undang. Tujuannya jelas, untuk mewujudkan keadilan substantif.

Dalam tulisan ini diajukan semacam pandangan awal bahwa keadilan sebagai dipahami selama ini tidaklah bertentangan secara diametris dengan kepastian hukum,

\footnotetext{
${ }^{7}$ Ibid, hal. 116

${ }^{8}$ Ibid, hal. 116
} 
melainkan berjalan seiring dan selaras dalam suatu aras tunggal. Bahwa kepastian hukum adalah kepastian tentang tegaknya suatu hukum yang dicita-citakan, dikonstitusi, dan dilaksanakan oleh masyarakat sebagai subjek utama dari hukum itu sendiri. ${ }^{9}$

Dalam kerangka pikir demikian, sebenarnya polemik mengenai dikotomi antara keadilan dan kepastian hukum dapat dijawab. Keadilan yang selama ini sering dimaknai keluar dari atau bertentangan dengan kepastian hukum patut untuk ditinjau ulang. Tulisan ini mencoba menguraikan hal tersebut secara singkat dengan pendekatan yuridis, filosofis, sosiologis, dan psikologis.

Dikotomi pemaknaan keadilan dan kepastian hukum muncul dari perbedaan dalam menafsirkan apa keadilan dan kepastian hukum itu. Diskursus mengenai hal ini berangkat dari titik tolak yang berbeda tentang pemaknaan hukum itu sendiri. Ketika sebagian yuris memahami dan memaknai hukum secara positivistik, sebagian lainnya memahami hukum dalam optik sosiologis yang erat kaitannya dengan konsep efektifitas hukum dan ketaatan hukum.

\section{B. Urgensi Obiter Dicta Dalam Putusan Hakim Perkara Perdata}

Obiter dicta merupakan terminologi yang berasal dari bahasa Latin. Obiter dicta tcrdiri atas dua frasa, yaitu "obiter" yang berarti "inpassing" dan "incidentally" atau "sambil lalu" dan "insidentil" serta "dicta" (jamak, tunggal "dictum") yang berarti "something that is said" atau "sesuatu yang dikemukakan". Dengan demikian, secara etimologi, obiter dicta adalah "something said in passing","things said by the way", atau "sesuatu yang dikemukakan secara sambil lalu atau insidentil". ${ }^{10}$

Dalam Black's Law Dictionary, obiter dicta (obiter dictum) didefinisikan sebagai:

"an observation or remark made by a judge in pronouncing an opinion upon a cause, concerning some rule, principle, or application of law, or the solution of a question suggested by the case at bar, but

\footnotetext{
9 Basuki Rekso Wibowo, Pembaruhan Hukum Yang Berwajah Keadilan, Majalah Varia Peradilan Tahun XXVII No. 313, Desember 2011, Jakarta, hal. 70

${ }^{10}$ Ibid, hal. 106
}

not necessarily involved in the case or essential to its determination". ${ }^{11}$

"pernyataan hakim berkaitan dengan pandangan atau pertimbangannya terhadap suatu kasus atau perkara, di dalamnya mencakup pandangan terhadap aturanaturan, prinsip-prinsip, maupun penerapan hukum, atau dapat juga merupakan jawaban atas pertanyaan-pertanyaan berkenaan dengan kasus tertentu, akan tetapi tidak berkaitan secara langsung dengan substansi (pokok permasalahan) suatu perkara".

Obiter dicta dalam putusan bersifat tidak mengikat (not binding) yang berbeda dengan ratio (yang mengikat), tetapi dapat menentukan putusan yang akan diambil. Obiter dicta merupakan pendapat atau pandangan hukum tertentu yang tidak berkaitan secara langsung dengan kasus atau perkara yang sedang ditangani. Obiter dicta dalam putusan (dalam tradisi common law) biasanya dipakai ketika hakim ingin menggunakan indikasi atau petunjuk-petunjuk tertentu dalam memutus suatu kasus yang serupa, tetapi tidak identik (berbeda dalam beberapa hal) dengan kasus yang sedang ditangani.

Tujuan dari penerapan obiter dicta dalam putusan adalah untuk memperjelas prinsipprinsip dan aturan-aturan hukum yang akan digunakan hakim dalam pertimbangannya. Dalam konteks demikian, obiter dicta pada umumnya dikemukakan dalam kontruksi yang analogis, ilustratif, poin-poin penting atau kesimpulan yang didasarkan pada hipotesis atas suatu keadaan. Meskipun tidak mengikat seperti halnya ratio decidendi, obiter dicta dapat diaplikasikan sebagai ratio decidendi dalam pertimbangan hukum atas kasus-kasus berikutnya. ${ }^{12}$

Berdasar penjelasan-penjelasan tersebut, dapat disimpulkan bahwa obiter dicta merupakan pernyataan atau proposisi hakim dalam mempertimbangkan suatu kasus atau perkara yang sedang ditanganinya tetapi tidak secara langsung bersentuhan atau berkaitan dengan pokok permasalahan (not directly relevant to the case).

\footnotetext{
${ }^{11}$ Henry Campbell Black, Black's Law Dictionary( Revised Fourth Edition), Minnesota West Publishing, 1968, hal. 241

${ }^{12}$ Ibid, hal. 242
} 
Poin penting yang perlu digaris bawahi adalah bahwa eksistensi obiter dicta tidak mengikat dan tidak pula wajib dikemukakan oleh hakim, yang sama sekali berbeda dengan ratio decidendi yang wajib dikemukakan sekaligus mengikat hakim dalam menjatuhkan putusan atas suatu perkara. Lazimnya, dalam tradisi hukum Indonesia, obiter dicta baru diaplikasikan jika dalam pemeriksaan suatu perkara, pokok permasalahan tidak terungkap secara gamblang, meskipun telah melalui suatu pembuktian yang panjang. Dalam konteks inilah, obiter dicta yang mewujud dalam analogi, ilustrasi, maupun hipotesa atas serangkaian fakta atau kejadian digunakan.

Sebagai contoh, dalam pemeriksaan perkara perceraian dengan alasan syiqaq (onheelbare tweespalt), ${ }^{13}$ sebagaimana maksud Pasal 19 huruf (f) PP Nomor 9 tahun 1975 tentang Pelaksanaan Undang-Undang Nomor 1 tahun 1974 tentang Perkawinan. Dalam pemeriksaannya, seringkali hakim kesulitan dalam mengungkap fakta hukum sebenarnya berkaitan dengan "perselisihan yang tajam dan terus-menerus" antara Penggugat dan Tergugat karena kesaksian para saksi tidak ada yang dapat mengungkap perselisihan dimaksud, seperti apa bentuknya, intensitasnya, kualitasnya, dan sebagainya.

Dari sinilah sesungguhnya hakim berangkat untuk turn over atau beralih ke obiter dicta, yaitu dengan mencoba mengungkap fakta-fakta kejadian lain yang tidak berhubungan langsung dengan pokok permasalahan syiqaq, tetapi dapat membuat jelas suatu permasalahan. Pengungkapan fakta-fakta dimaksud dirumuskan dalam pertanyaan-pertanyaan tertentu, misalnya: ${ }^{14}$

1. Apakah Penggugat dan Tergugat masih sering makan bersama?

2. Apakah Penggugat dan Tergugat masih menghadiri undangan pernikahan bersama?

3. Apakah Penggugat dan Tergugat masih sering bercanda atau membicarakan hal-hal tertentu?

Semua pertanyaan tersebut diajukan

\footnotetext{
13 Lihat PP Nomor 9 Tahun 1975, tentang pelaksanaan Undang-Undang No. 1 Tahun 1974 tentang Perkawinan, Pasal 19 Huruf ( $f$ )

14 Moh. Taufik Makarao, Pokok-Pokok Hukum Acara Perdata, Rineka Cipta, Jakarta, 2009, hal. 42
}

dengan asumsi dasar bahwa suatu perkawinan yang pada awalnya harmonis biasanya diwarnai dengan kegiatan suami istri secara bersamasama, baik itu makan bersama, ke pesta bersama, bercanda bersama, diskusi bersama, dan sebagainya. Suatu perkawinan yang telah pecah salah satunya dapat diindikasikan dengan hilangnya kebiasaan-kebiasaan bersama tersebut, meskipun pertengkaran nyata, baik ucapan secara verbal maupun tindakan tertentu tidak tampak, karena pada beberapa pasangan suami istri, perselisihannya justru berwujud pada sikap saling mendiamkan satu sama lain, memutus komunikasi, dan aktivitas-aktivitas tersembunyi lainnya (indicated by silent activity). Bukankah ketika rumah tangga masih harmonis, keinginan untuk berbagi satu sama lain sangat besar sehingga kecenderungan untuk melakukan hal secara bersama-sama juga besar? Inilah yang dalam tradisi common law dipersepsikan sebagai obiter dicta yang antara lain diwujudkan dalam analogi, ilustrasi, maupun penarikan suatu hipotesis atas satu atau beberapa kejadian.

Penulis akan menjelaskan sedikit tentang sengketa perkawinan yang dijelaskan sebelumnya. Suatu gugatan cerai didasarkan pada alasan yang dikemukakan Pasal 19 huruf (f) PP Nomor 9 Tahun 1975, yaitu perselisihan yang tajam dan terus-menerus yang tidak mungkin didamaikan lagi (pokok permasalahan). Proses untuk menerapkan obiter dicta dalam kasus tersebut adalah sebagai berikut:

1. Dalam persidangan, ternyata para saksi tidak melihat atau mengetahui adanya perselisihan atau pertengkaran dimaksud (pokok permasalahan tidak terungkap). Jika permasalahan terungkap, maka Hakim tidak akan menggunakan obiter dicta, melainkan akan menggunakan ratio decidendi ${ }^{15}$.

\footnotetext{
15 Ratio decidendi (terminologi Latin, jamak rationes decidendi) adalah dasar atau alasan hakim dalam memutus suatu perkara (rational for decision). Ratio decidendi ini merupakan point penting yang menentukan pertimbangan hukum hakim dalam mengabulkan atau menolak gugatan penggugat. Berbeda dengan obiter dicta, ratio decidendi merupakan ketentuan umum yang mengikat hakim dalam memutus suatu perkara. Proses atau tahapan dalam menentukan ratio decidendi suatu putusan didasarkan pada substansi atau pokok sengketa
} 
2. Hakim kemudian mengajukan pertanyaanpertanyaan tertentu kepada para saksi untuk menemukan indikator akhir (misalnya tidak makan bersama, tidak ke pesta bersama, sering saling mendiamkan, dan sebagainya) untuk kemudian membandingkannya dengan indikator awal (misalnya ketika rukun dan harmonis masih makan bersama, ke pesta bersama, aktif berkomunikasi, dan sebagainya).

3. Jika indikator akhir berhasil ditemukan, maka Hakim akan melakukan analisis dengan analogi, ilustrasi maupun hipotesis (misalnya, Penggugat dan Tergugat sudah tidak rukun lagi dan terlibat perselisihan yang terus-menerus karena kebiasaankebiasaan awal sewaktu rumah tangga Penggugat dan Tergugat masih harmonis tidak pernah lagi dilakukan)

4. Dengan dasar obiter dicta tersebut, hakim dapat mengabulkan gugatan cerai Penggugat, tetapi sekali lagi, obiter dicta tidak mengikat hakim.

Pada bagian sebelumnya telah dikemukakan bahwa obiter dicta sejatinya merupakan pandangan hakim yang dibangun atas suatu fakta yang tidak secara langsung bersentuhan atau berkaitan dengan pokok perkara. Dalam penerapannya, obiter dicta lebih cenderung diaplikasikan ketika suatu pokok sengketa tidak terungkap dalam persidangan. Hal ini dapat disebabkan karena keterbatasan pengetahuan saksi mengenai pokok sengketa maupun karena konstruksi sengketa yang sedemikian rumit.

Ketentuan mengenai obiter dicta secara implisit terdapat dalam Pasal 170 HIR dan Pasal 1906 KUHPdt. Pasal 170 HIR menyebutkan: ${ }^{16}$

"Jika kesaksian-kesaktian yang terpisahpisah dan berdiri sendiri dari beberapa orang tentang beberapa kejadian dapat meneguhkan perkara tertentu karena kesaksian-kesaksian itu sesuai dan berhubungan satu sama lain, maka kekuatan bukti hukum sepanjang yang akan diberikan kepada kesaksian-kesaksian yang beraneka ragam itu, hal itu diserahkan kepada pertimbangan hakim, berhubung dengan keadaan"

serta aturan hukum apa yang berkaitan dengannya (http://en.wikipedia.org/wiki/Ratio decidendi)

${ }^{16}$ Lihar Pasal 170 HIR
Kemudian dalam Pasal 1906 KUHPdt, disebutkan: ${ }^{17}$

"Jika kesaksian-kesaksian berbagai orang mengenai berbagai peristiwa terlepas satu sama lain, dan masing-masing berdiri sendiri, namun menguatkan suatu peristiwa tertentu karena mempunyai kesesuaian dan hubungan satu sama lain, maka Hakim, menurut keadaan, bebas untuk memberikan kekuatan pembuktian kepada kesaksiankesaksian yang berdiri sendiri itu."

Dari kedua pasal tersebut, dapat dipahami bahwa kesaksian para saksi di persidangan dapat berbeda satu sama lain. Berbeda di sini adalah peristiwa yang dikemukakan oleh para saksi saling berlainan, akan tetapi dari keterangan-keterangan tersebut justru dapat ditarik suatu benang merah atau kesimpulan. Dengan demikian, dari ketentuan tersebut di atas, dapat disimpulkan hal-hal sebagai berikut: 18

a. Obiter dicta mencakup kesaksian yang berbeda tentang suatu peristiwa yang berdiri sendiri. Misalnya Saksi A menyatakan bahwa Penggugat ke pesta perkawinan sendiri, tidak pernah ditemani Tergugat, kemudian Saksi B mengemukakan bahwa Tergugat lebih sering membeli makanan di luar sementara sebelumnya, Tergugat jarang atau bahkan tidak pernah membeli makanan di luar, dan Saksi C mengemukakan bahwa Penggugat mengantarkan anak ke sekolah sendiri, tidak lagi ditemani oleh Tergugat;

b. Kesaksian-kesaksian yang berbeda tersebut memiliki keterkaitan satu sama lain, meskipun peristiwa yang dikemukakan adalah peristiwa tunggal atau berdiri sendiri. Berdasar contoh pada huruf (a) tadi, masingmasing kesaksian memiliki hubungan atau keterkaitan satu sama lain, yaitu bahwa Penggugat dan Tergugat mengerjakan atau melakukan aktivitas sehari-hari secara sendiri-sendiri, tidak lagi secara bersamasama sebagaimana dahulu;

c. Kesaksian-kesaksian yang terpisah-pisah tersebut ternyata dapat meneguhkan suatu perkara, dalam hal ini dapat memperjelas

\footnotetext{
${ }^{17}$ R. Subekti Tjitrosudibio, Kitab Undang-Undang Hukum Perdata, Pradnya Paramita, Jakarta, 1978

${ }^{18}$ M. Natsir Asnawi, Loc Cit, hal. 111
} 
pokok sengketa. Berdasar ilustrasi pada huruf (a) dan (b) tadi, maka kesaksiankesaksian tersebut dapat memperjelas atau mengungkap suatu fakta bahwa hubungan atau ikatan lahir dan batin antara Penggugat dan Tergugat sudah renggang, rumah tangga Penggugat dan Tergugat sudah tidak harmonis, serta tidak ada atau kurangnya kesepahaman antara Penggugat dan Tergugat;

d. Berdasar hal tersebut, hakim bebas untuk memilih apakah akan menggunakan petunjuk-petunjuk tersebut untuk mencapai suatu kesimpulan bahwa rumah tangga antara Penggugat dan Tergugat sudah retak atau tidak. Hal tersebut bergantung pada keyakinan hakim, bahwa fakta-fakta yang terungkap sudah membuktikan bahwa antara Penggugat dan Tergugat terusmenerus terjadi perselisihan sehingga rumah tangga demikian sudah tidak mungkin lagi dipertahankan.

Obiter dicta sendiri pada dasarnya tidak hanya mencakup analisis terhadap fakta-fakta yang tidak secara langsung berkaitan dengan pokok sengketa. Obiter dicta dapat pula menyentuh sisi aturan maupun prinsip hukum serta penerapannya. Sebagai contoh, salah satu kaidah yurisprudensi yang diabstraksi dari Putusan Mahkamah Agung Nomor 608 K/AG/2003 tanggal 23 Maret 2005 menyebutkan bahwa nafkah lampau anak yang tidak terbayarkan bersifat lil intifa' bukan li tamlik. Kaidah tersebut lahir dari analisis hakim yang mengadili perkara tersebut bahwa pada dasarnya, nafkah anak ditujukan untuk kepentingan dan kemanfaatan bagi anak. ${ }^{19} \mathrm{Jika}$ hal tersebut diabaikan oleh ayahnya, sementara anak tersebut tetap tumbuh kembang secara wajar, maka isteri tidak dapat menuntutnya karena nafkah dimaksud bukan hak milik istri.

Lahirnya kaidah tersebut didasarkan pada kenyataan bahwa dalam pokok sengketa dimaksud, ditemukan fakta bahwa anaknya tetap tumbuh secara wajar, sehingga penerapan aturan hukum terkait kewajiban ayah menafkahi anaknya tidak dapat ditarik untuk diberlakusurutkan. Kaidah yang lahir

19 Jurisprudensi Putusan Mahkamah Agung RI No. 608 K/AG/2003, tanggal 23 Maret 2005 tersebut ternyata kemudian mempengaruhi pemikiran sebagian hakim mengenai kedudukan, fungsi, dan dinamika nafkah anak yang terbukti dengan menjadi yurisprudensi Mahkamah Agung (ruling in a subsequent case).

Disinilah sesungguhnya urgensi obiter dicta dalam putusan hakim. Meskipun tidak wajib dan tidak mengikat bagi hakim, akan tetapi dalam kasus tertentu yang pokok sengketanya tidak terungkap, obiter dicta menjadi teramat penting. Karena itu, sudah sepatutnya hakim untuk tidak hanya berfokus pada pokok sengketa, tetapi lebih jauh menganalisis hal-hal atau fakta-fakta maupun aturan dan prinsipprinsip hukum yang tidak berkaitan langsung dengan pokok sengketa tadi.

Penulis ingin mengemukakan satu contoh lain perihal pentingnya obiter dicta. Dalam kasus kewarisan misalnya, hakim berhasil mengungkapkan fakta bahwa A sebagai laki-laki dalam kesehariannya hanya menghabiskan harta pewaris dan bahkan pernah mencoba mengelabui pewaris dengan menjual salah satu aset terbaiknya, yaitu rumah. Sementara itu, B sebagai perempuan ternyata menggunakan harta pewaris dengan sebaik-baiknya, bahkan sangat mengutamakan bagi terpenuhinya kebutuhan pewaris sampai yang bersangkutan meninggal dunia. Selain itu, B ternyata sangat menjaga harta pewaris dan bertekad akan menggunakannya untuk kepentingan seluruh anggota keluarga. Dengan fakta demikian, hakim menerapkan obiter dicta dengan mengaitkan fakta tadi (yang tidak bersentuhan langsung dengan pokok sengketa) dengan substansi dari ketentuan perundang-undangan mengenai bagian waris. Akhirnya, hakim memutuskan bahwa $B$ sebagai perempuan mendapatkan dua bagian waris, sementara $A$ sebagai laki-laki mendapat satu bagian waris.

Pada beberapa putusan pengadilan yang menerapkan obiter dicta, dapat disimpulkan bahwa penerapan tersebut didasarkan pada keinginan untuk memutus secara lebih adil, dan sedapat mungkin tetap menciptakan kepastian hukum dan kemanfaatan. Karena itu, sangat beralasan bagi para hakim untuk mulai melirik dan menerapkannya secara massif dalam memeriksa, mengadili, dan memutus sengketa yang ditanganinya.

Putusan hakim didasarkan pada 
pertimbangan yang utuh dan komprehensif mengenai fakta-fakta hukum yang menjadi pokok perkara. Hakim dalam memeriksa, mengadili, dan memutus suatu perkara akan diperhadapkan pada kompleksitas kasus yang berbeda antara satu dengan lainnya. Dua perkara misalnya, meskipun memiliki topik yang sama, namun duduk perkaranya berbeda dengan tingkat kompleksitas yang berbeda pula.

Tidak jarang dalam pemeriksaan suatu perkara pokok perkara tidak dapat terungkap yang pada akhirnya menyulitkan hakim dalam menyusun pertimbangan hukum. Ratio decidendi (reasons of the judgment) adalah pertimbangan hukum yang dipakai hakim dalam memutus suatu perkara. Dalam ratio decidendi, hakim akan menghubungkan faktafakta hukum (pokok perkara) dengan ketentuan perundang-undangan yang berkaitan dengan hal itu. Pada proses selanjutnya, hakim berupaya menemukan hukumnya dengan menggunakan berbagai pisau analisis (metode) seperti penafsiran (interpretation) maupun konstruksi hukum (rechtschepping, law making). ${ }^{20}$

\section{PENUTUP}

\section{A. Kesimpulan}

1. Keadilan dan kepastian hukum merupakan dua entitas yang tidak dapat dipisahkan yaitu:

a. Keadilan adalah sebagai tujuan tertinggi hukum (The Ultimate Goal) yang ingin dicapai dalam suatu penegakkan hukum, keadilan adalah cita-cita luhur yang lahir dan senantiasa tumbuh bersama masyarakat.

b. Kepastian hukum sebenarnya dapat dipahami sebagai buah proses atau dinamika hukum yang selama ini hidup dan berkembang dan dijalani oleh masyarakat yang dimaksud adalah yang memenuhi tiga kriteria umum yaitu:

- Ius constitutum;

- lus constituendum;

${ }^{20}$ M. Syamsuddin, Mengenai Tipologi Perilaku Hakim dalam Memutuskan Perkara, Majalah Media Informasi Hukum dan Keadilan Komisi Yudisial, Edisi Mei-Juni 2013.
- lus operatum.

2. - Obiter Dicta merupakan pernyataan dan proposisi hakim dalam mempertimbangkan suatu kasus atau perkara yang sedang ditanganinya tentang tidak secara langsung bersentuhan atau berkaitan dengan pokok perkara (not directly relevant to the case).

- Obiter dicta secara implisit terdapat dalam Pasal 170 HIR dan Pasal 1906 KUHPerdata.

\section{B. Saran}

1. Pemaknaan kepastian hukum perlu rekonstruksi ulang, karena selama ini kepastian hukum cenderung dimaknai sebagai status quo, suatu keadaan yang sudah menetap dan cenderung dipertahankan untuk menjaga kestabilan suatu aturan.

2. Diharapkan agar obiter dicta dapat dipertimbangkan oleh para hakim terutama kasus-kasus perdata, dengan tujuan agar penerapan obiter dicta untuk memperjelas prinsip-prinsip dan aturanaturan hukum yang akan digunakan oleh hakim dalam pertimbangan hukumnya.

\section{DAFTAR PUSTAKA}

Aritonang Baharudin dan Muslim Hutasoit, Undang-Undang Kekuasaan Kehakiman, Pustaka Pergaulan, Jakarta, 2004.

Asnawi M. Natsir, Kekuasaan Kehakiman Dalam Perspektif Politik Hukum, Majalah Peradilan Tahun XXVII No. 332, Jakarta, 22 Juli 2003.

Basiang Marthin, The Contemporary Law Dictionary (First Edition), Red \& White Publishing, 2009

Campbell Henry Black, Law Dictionary (Revised Fourth Edition), Minesota West Publishing, 1968

Djamali R. Abdoel, Pengantar Hukum Indonesia, Rajawali, Jakarta, 1984

Effenddi Jon, $K Y$ dan Intervensi Putusan Hakim, 2011, http://padangekspres. co.id/news=nberita\&id=280

Fuady Munir, Dinamika Teori Hukum, Ghalia Indonesia, Jakarta, 2007

Gultom Binsar, Kualitas Putusan Hakim Harus Didukung Oleh Masyarakat, Suara 
Pembaharuan, 20 April 2006.

Hamzah, Andi, Kamus Hukum, Ghalia Indonesia, Jakarta, 1986

Harahap M. Yahya, Hukum Acara Perdata, Tentang Gugatan,Sinar Grafika, 2008

Ibrahim Johny, Teori dan Metodologi Penelitian Hukum Normatif, Bahu Media, Surabaya, 2007.

Lotulung Paulus E, Mewujudkan Putusan Yang Berkualitas Rasa Keadilan, Peradilan Tata Usaha Negara, Rapat Kerja Tanggl 10 Oktober 2010

Makarao Moh. Taufik, Pokok-Pokok Hukum Acara Perdata, Rineka Cipta, Jakarta, 2009

Manan Bagir, Hukum Positif Indonesia Suatu Kajian Teoritik, Yogyakarta, UII Press, 1981.

Manan H. Abdul, Penerapan Hukum Acara Perdata di Lingkungan Peradilan Agama, Kencana, Jakarta, 2006

Mertokusumo Sudikno, Hukum Acara Perdata di Indonesia, Liberty, Yogyakarta, 1988.

Muhammad Abdulkadir, Hukum Acara Perdata di Indonesia, Alumni, Bandung, 1986.

Rasais M. Nur, Hukum Acara Perdata, Sinar Grafika, Jakarta, 2003.

Rekso Wibowo Basuki, Pembaharuan Hukum Yang Berwajah Keadilan, Varia $\mathrm{p}$

Rifai Ahmad, Penemuan Hukum Oleh Hakim Dalam Perspektif Hukum Progresif, Bumi Aksara, Jakarta, 2011.

Saleh K. Wantjik, Hukum Acara Perdata $H I R / R b g$, Ghalia Indonesia, Jakarta, 1981.

Siregar Bismar, Hukum Hakim dan Keadilan Tuhan, Kumpulan Catatan Hukum dan Peradilan di Indonesia, Gema Insani Press, Jakarta, 1995.

Soekanto Soerjono, Pengantar Penelitian Hukum, UI Press, Jakarta, 1986.

Subekti R., Hukum Pembuktian, Pradnya Paramita, Jakarta, 2010.

Sutantiek Sri, Menyoal Akuntabilitas Moral Hakim Pidana dalam Memeriksa, Mengadili dan Memutuskan Perkara, Aswaja Pressindo, Yogyakarta, 2013

Syahrani Riduan, Himpunan Peraturan Hukum Acara Perdata Indonesia, Alumni, Bandung, 1991.

Syamsudin M, Mengenai Tipologi Perilaku Hakim Dalam Memutuskan Perkara, Majalah Media Informasi Hukum Dan Keadilan, Mei-Juni 2013
Tresna R, Komentar HIR, Pradnya Paramita, Jakarta, 1980

Yuti Winanto Darmoko dan Arya Putra Negara Kertawaringin, Direksi Hakim Sebuah Instrumen Menegakkan Keadilan Substantif dalam Perkara Pidana, Alfabeta, Bandung, 2013. 